\title{
In vitro Antioxidant and Anti-obesity Activities of Freeze-dried Canarium sp., Averrhoa bilimbi L. and Malus domestica
}

\author{
Sri Utami ${ }^{1, *}$, Susi Endrini ${ }^{1}$, Said Nafik ${ }^{2}$, Intan Meila Tria Lestari ${ }^{1}$, Dea Anindya ${ }^{1}$, \\ Engkay Abu Bakar ${ }^{1}$, Fahrul Rozy ${ }^{1}$, Fathonah Fatimatuzahra Said ${ }^{1}$, Ervi Afifah ${ }^{3}$, \\ Seila Arumwardana ${ }^{3}$, Hayatun Nufus ${ }^{3}$, Dwi Davidson Rihibiha ${ }^{3}$, Hanna Sari Widya Kusuma ${ }^{3}$, \\ Satrio Haryo Benowo Wibowo ${ }^{3}$, Wahyu Widowati ${ }^{4}$ \\ ${ }^{1}$ Faculty of Medicine, Universitas YARSI, Jl. Letjend Suprapto, Jakarta, Indonesia \\ ${ }^{2}$ Directorate General of Intellectual Property, Ministry of Law and Human Rights, Republic of Indonesia, J1. H.R. Rasuna Said, Jakarta, Indonesia \\ ${ }^{3}$ Aretha Medika Utama, Biomolecular and Biomedical Research Center, Jl. Babakan Jeruk 2 No. 9, Bandung, Indonesia \\ ${ }^{4}$ Faculty of Medicine, Universitas Kristen Maranatha, Jl. Prof. Drg. Surya Sumantri No. 65, Bandung, Indonesia \\ *Corresponding author. E-mail: uutsuyono@yahoo.com
}

Received date: Jun 25, 2019; Revised date: Sep 5, 2019; Accepted date: Sep 9, 2019

\section{Abstract}

$\mathrm{B}$

ACKGROUND: The number of obesity cases is still increasing worldwide and has reached an epidemic scale. Plants are known to have a protection role in the development of obesity, however their antioxidant and anti-obesity activities have not widely known. This study was conducted to assess the in vitro antioxidant and anti-obesity activities of different types of freeze-dried fruits cultivated in Indonesia, especially Canarium sp., Averrhoa bilimbi L. and Malus domestica.

METHODS: Total phenolic content of freeze-dried fruits was identified by Folin-Ciocalteu method, while the total flavonoid content was measured by aluminium chloride colorimetric assay. To assessed the antioxidant activity, 2,2-diphenyl 1-picrylhydrazyl (DPPH) scavenging activity assay and 2,2'-azino-bis (3-ethylbenzothiazoline6-sulphonic acid) (ABTS) reducing activity assay were performed. The $\alpha$-amylase and lipase inhibitory activity assay were performed to assess the anti-obesity activity. For comparison, hydroxycitric acid (HCA) compound was also assessed with DPPH, ABTS, $\alpha$-amylase and lipase assays.

RESULTS: $A$. bilimbi had the highest total phenol content (6.35 $\mu \mathrm{g} \mathrm{GAE} / \mathrm{mg})$, meanwhile $M$. domestica had the highest total flavonoid content $(2.06 \mu \mathrm{g} \mathrm{QE} / \mathrm{mg})$. $A$. bilimbi also showed the highest antioxidant activity both in DPPH and ABTS assay, with inhibitory concentration $\left(\mathrm{IC}_{50}\right)=279.99 \mu \mathrm{g} / \mathrm{mL}$ and $631.78 \mu \mathrm{g} / \mathrm{mL}$, respectively. The freeze-dried $M$. domestica had the highest anti- $\alpha$-amylase activity $\left(\mathrm{IC}_{50}=258.85 \mu \mathrm{g} / \mathrm{mL}\right.$ ), while Canarium sp. had the highest anti-lipase activity $\left(\mathrm{IC}_{50}=118.66 \mu \mathrm{g} / \mathrm{mL}\right)$.

CONCLUSION: Freeze-dried fruits demonstrate in vitro benefits toward obesity. A. bilimbi has potent antioxidant activity and is beneficial against obesity-related adverse health effect by relieving oxidative stress. $M$. domestica and Canarium sp. hamper the fat accumulation by reducing the carbohydrate absorption and dietary lipid.

KEYWORDS: antioxidant, anti-obesity, Canarium sp., Averrhoa bilimbi L., Malus domestica, hydroxycitric acid

Indones Biomed J. 2019; 11(3): 320-6

\section{Introduction}

Obesity is defined as excessive body fat accumulation, which increase the risk of adverse health effect. As described by World Health Organization (WHO), people with body mass index (BMI) over $30 \mathrm{~kg} / \mathrm{m}^{2}$ are diagnosed as obese.(1) In Indonesia, the BMI of $22.9 \mathrm{~kg} / \mathrm{m}^{2}$ is considered to be the normal weight.(2)

In recent years, the number of obesity cases is still increasing worldwide up to 650 million in adults (3), and has reached the epidemic scale, especially in high-income 
countries (4). Obesity is the main preventable cause of death. An obese person has a higher risk of developing various adverse health effects, including cardiovascular diseases and diabetes.(5) There are multiple risk factors ranging from an unhealthy lifestyle to genetics that contribute to the pathogenesis of obesity.(6) Oxidative stress, a condition caused by excessive production of reactive oxygen species (ROS), plays an important role in the development of obesity and its adverse health effect. $(7,8)$

Plants are the source of multitude phytochemical compounds that are useful in various biological activities. Previous study found that several plant extracts were able to prevent fat absorption through the inhibition of pancreatic lipase.(9) Other study demonstrated that plant extract could protect an animal model from hyperglycemia.(10) Nowadays, the use of fruits continues to be developed, considering its less side effects and toxicity.

Despite its many benefits, fruits are easily spoiled. Thus, diverse methods are found to preserve fruits, one of which is the freeze-drying technique.(11) Freeze-drying technique is known to have many advantages to maintain fruits and its phytochemicals quality. By using the technique, the colour stability and anthocyanin content in fruit are able to be preserved.(12)

Unfortunately, the antioxidant and anti-obesity activities of several common fruits found in Indonesia, such as Canarium sp. (galip nut), Averrhoa bilimbi L. (star fruit) and Malus domestica (apple), especially when preserved with freeze-drying technique, still has not widely known. To address this, the freeze-dried Canarium sp., A. bilimbi and $M$. domestica fruit samples were assessed by antioxidant and anti-obesity assays. This study aimed to describe the possible benefit of freeze-dried fruits cultivated in Indonesia against obesity.

\section{Methods}

\section{Freeze-dried Samples Material}

The Canarium sp., A. bilimbi and M. domestica samples were obtained from the plantations located in Jawa Barat and Jawa Timur, Indonesia. The plants were identified at the School of Life Sciences and Technology, Bandung Institute of Technology, Bandung, Indonesia. As much as $1.35 \mathrm{~kg}$ Canarium sp., $1.6 \mathrm{~kg} \mathrm{~A}$. bilimbi and $2 \mathrm{~kg}$ of M. domestica were washed and milled, before being freeze-dried using the freeze drier (Nanbei, Henan, China), which resulted in 28.22 gram freeze-dried Canarium sp., 9.98 gram freezedried A. bilimbi and 57.6 gram freeze-dried M. domestica.
For comparison, hydroxycitric acid (HCA) compound (Cat \#59847-5G, Sigma Aldrich, Missouri, USA), a derivative of citric acid which is found in some tropical plants, was also prepared and further analysed.

\section{The Identification of Total Phenolic Content}

The total phenolic content in freeze-dried fruit samples was evaluated using the modified colorimetric method. The method was marked by the reduction of Folin-Ciocalteu reagent (Cat \#1.09001.0500, Merck, Darmstadt, Germany) by phenolic compounds with a concomitant formation of a blue complex. Each freeze-dried fruit samples and 100 $\mu \mathrm{L}$ of gallic acid standard was mixed with $75 \mu \mathrm{L}$ of $10 \%$ Follin-Ciocaltaeu reagent and $60 \mu \mathrm{L}$ of $7.5 \% \mathrm{Na}_{2} \mathrm{CO}_{3}$ in the microplate, and then was incubated at the temperature of $45-50^{\circ} \mathrm{C}$ for 10 minutes. The absorbance was measured in $750 \mathrm{~nm}$ of wavelengths using the microplate reader. $(13,14)$

\section{The Identification of Total Flavonoid Content}

The total flavonoid content of freeze-dried fruits was measured by aluminium chloride colorimetric assay. Briefly, each freeze-dried fruit samples and $250 \mu \mathrm{L}$ of standard was mixed with $75 \mu \mathrm{L}$ of $5 \% \mathrm{NaNO}_{2}$. After 6 minutes, $150 \mu \mathrm{L}$ of $10 \% \mathrm{AlCl}_{3} \cdot \mathrm{H}_{2} \mathrm{O}$ solution was added. After another 5 minutes, $0.5 \mathrm{~mL}$ of $1 \mathrm{M} \mathrm{NaOH}$ solution was added to the mixture. The final mixture was measured using the microplate reader absorbance at $510 \mathrm{~nm}$ of wavelength.(15)

\section{The 2,2-diphenyl-1-picrylhydrazyl (DPPH) Scavenging Activity Assay}

To evaluate the antioxidant activity, the DPPH assay was conducted. Fifty $\mu \mathrm{L}$ of freeze-dried fruit samples and HCA at various concentrations were added to the 96 -well microplate. Two-hundred $\mu \mathrm{L}$ of DPPH solution (Cat \#D913-2, Sigma Aldrich) was then added into each well, and was incubated at $20-25^{\circ} \mathrm{C}$ in the darkroom for 30 minutes. The absorbance was measured at $517 \mathrm{~nm}$ of wavelengths using Multiskan ${ }^{\mathrm{TM}}$ GO Microplate Spectrophotometer (Thermo Scientific, Massachusetts, USA). A $250 \mu \mathrm{L}$ of DPPH solution was used as the negative control, while $250 \mu \mathrm{L}$ of methanol was used as the blank control. The scavenging activity was measured based on the sample DPPH absorption rate in comparison to negative control. $(14,16)$

The 2,2'-azino-bis(3-ethylbenzothiazoline-6-sulphonic acid (ABTS)-reducing Activity Assay

Two $\mu \mathrm{L}$ of each freeze-dried fruit samples and HCA were added to the sample well, then $198 \mu \mathrm{L}$ of ABTS solution (Cat \#A1888-2G, Sigma Aldrich) was added to each well, 
and was incubated at $30^{\circ} \mathrm{C}$ for 6 minutes. The absorbance was measured every 1 minute at $420 \mathrm{~nm}$ of wavelength using the Multiskan ${ }^{\mathrm{TM}}$ GO Microplate Spectrophotometer reader (Thermo Scientific) for 8 minutes.(14,16-18) This method was done to evaluate the antioxidant activity.

\section{The $\alpha$-amylase Inhibitory Activity Assay}

To assess the anti-obesity activity of each freeze-dried fruits and HCA, $\alpha$-amylase inhibitory activity assay were performed. Thirty $\mu \mathrm{L}$ of each freeze-dried fruit samples and HCA were added into the sample and negative control well, while $30 \mu \mathrm{L}$ of dimethyl sulfoxide (DMSO) was served as the blank control. Ten $\mu \mathrm{L}$ of $\alpha$-amylase enzyme (Cat \#759550ML, Sigma Aldrich) was added into each well, except for the blank control well. After incubated at $37^{\circ} \mathrm{C}$ for 10 minutes, $40 \mu \mathrm{L}$ starch solution was added to each well except for the negative control well. Forty $\mu \mathrm{L}$ of phosphate buffer was then added to the negative control well, and was incubated at $37^{\circ} \mathrm{C}$ for 15 minutes. The enzymatic reaction was terminated by the addition of $100 \mu \mathrm{L}$ of acidic iodine solution in each well. The absorbance was measured at 565 $\mathrm{nm}$ of wavelength using the Multiskan ${ }^{\mathrm{TM}}$ GO Microplate Spectrophotometer (Thermo Scientific).(16,19,20)

\section{The Lipase Inhibitory Activity Assay}

Lipase inhibitory activity assay to evaluate the anti-obesity activity was performed based on following procedures. Twenty $\mathrm{mL}$ of each freeze-dried fruit samples and HCA, $20 \mathrm{~mL}$ of porcine pancreas lipase (PPL) enzyme (Cat \#L3126-100G, Sigma Aldrich), and $100 \mathrm{~mL}$ of potassium phosphate buffer were added to the 96-well microplate, and then was incubated at $37^{\circ} \mathrm{C}$ for 1 hour. Furthermore, 10 $\mathrm{mL}$ of nitrophenyl butyrate (NPB) (Cat \#N9876-1G, Sigma Aldrich) substrate was added, and was incubated at $37^{\circ} \mathrm{C}$ for 5 minutes. The absorbance was measured at $405 \mathrm{~nm}$ of wavelength. $(19,21)$

\section{Results}

\section{Total Phenolic Content}

Total phenolic content of each freeze-dried fruits was evaluated. The result was expressed in $\mu \mathrm{g}$ gallic acid equivalent (GAE)/mg. Freeze-dried A. bilimbi had the highest level of phenolic content compared to the other two freeze-dried fruits, with the concentration of $6.35 \pm 0.95 \mu \mathrm{g}$ GAE/mg. Meanwhile, the lowest concentration of phenol was found in the freeze-dried $M$. domestica $2.46 \pm 0.93 \mu \mathrm{g}$ GAE/mg (Table 1).

\section{Total Flavonoid Content}

The flavonoid content of freeze-dried fruits was also evaluated. The result was expressed in $\mu \mathrm{g}$ quercetin equivalent $(\mathrm{QE}) / \mathrm{mg}$. Freeze-dried $M$. domestica had the highest level of flavonoid content compared to the other freeze-dried fruits, with concentration of $2.06 \pm 0.46 \mu \mathrm{g} \mathrm{QE} /$ $\mathrm{mg}$, while the lowest was the freeze-dried Canarium sp., with the concentration of $0.04 \pm 0.32 \mu \mathrm{g} \mathrm{QE} / \mathrm{mg}$ (Table 1).

Table 1. Total phenolic and total flavonoid content of the freeze-dried fruits.

\begin{tabular}{lcc}
\hline $\begin{array}{c}\text { Freeze-dried Fruit } \\
\text { Sample }\end{array}$ & $\begin{array}{c}\text { Total Phenolic } \\
\text { Content } \\
(\boldsymbol{\mu g} \text { GAE/mg) }\end{array}$ & $\begin{array}{c}\text { Total Flavonoid } \\
\text { Content } \\
(\boldsymbol{\mu g} \mathbf{Q E} / \mathbf{m g})\end{array}$ \\
\hline Canarium sp. & $6.07 \pm 0.50$ & $0.04 \pm 0.32$ \\
Averrhoa bilimbi L. & $6.35 \pm 0.95$ & $0.29 \pm 0.48$ \\
Malus domestica & $2.46 \pm 0.93$ & $2.06 \pm 0.46$ \\
\hline
\end{tabular}

*The data was presented as mean \pm standard deviation.

\section{DPPH Scavenging Activity}

The antioxidant activity of each freeze-dried fruits and HCA based on DPPH scavenging assay were evaluated. Based on the result, freeze-dried A. bilimbi had the highest DPPH scavenging activity (49.73\%) when compared to the freeze-dried Canarium sp., freeze-dried M. domestica and HCA (Figure 1A). Based on the inhibitory concentration $\left(\mathrm{IC}_{50}\right)$ values, freeze-dried A.bilimbi also showed the highest scavenging activity $(279.99 \mu \mathrm{g} / \mathrm{mL})$, compared to the other three compounds (Table 2).

\section{ABTS-reducing Activity}

The antioxidant activities of each freeze-dried fruits and HCA were also evaluated based on the ABTS assay. The freeze-dried A. bilimbi had the highest percentage in ABTSreducing activity $(12.46 \%)$ compared to freeze-dried Canarium sp., freeze-dried M. domestica and HCA (Figure 1B). The $\mathrm{IC}_{50}$ value was calculated, HCA had the highest ABTS-reducing activity $(166.23 \mu \mathrm{g} / \mathrm{mL})$, and followed by freeze-dried $A$. bilimbi $(634.37 \mu \mathrm{g} / \mathrm{mL})$ which had the highest value among the three freeze-dried fruits, whereas the freeze-dried $M$. domestica had the lowest ABTSreducing activity $(3183.41 \mu \mathrm{g} / \mathrm{mL})$ (Table 2$)$.

\section{a-amylase Inhibitory Activity}

To assess the anti-obesity of each freeze-dried fruits and HCA, the $\alpha$-amylase inhibitory activity was evaluated. Figure 2A showed that freeze-dried M. domestica had the 
$\mathbf{A}$

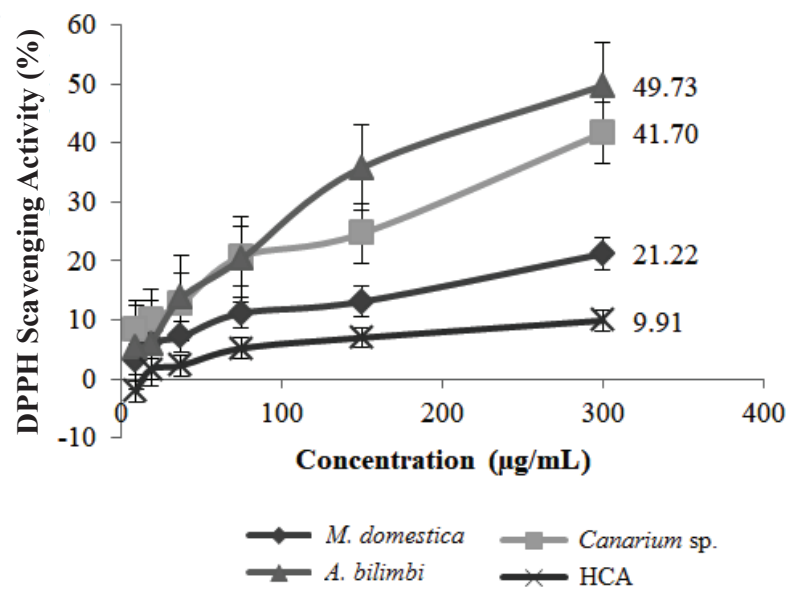

B

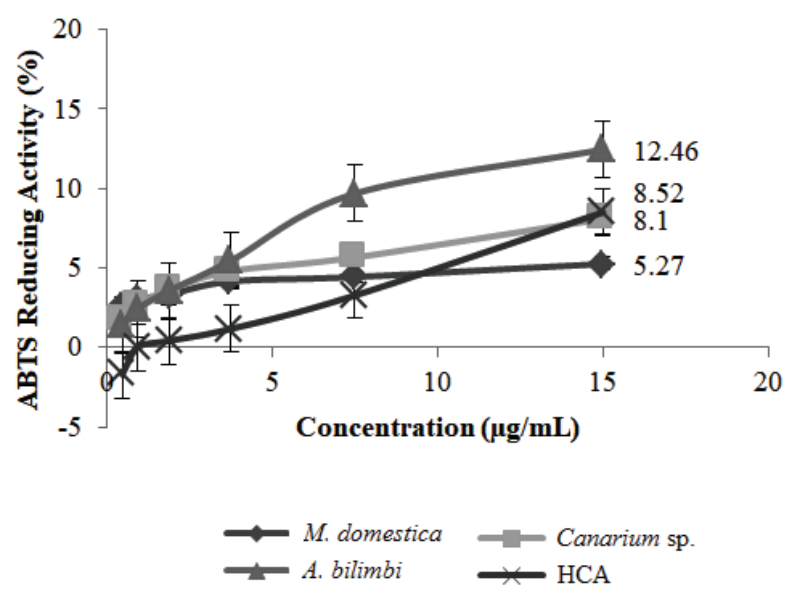

Figure 1. Concentration of freeze-dried Canarium sp., Averrhoa bilimbi L., Malus domestica, and HCA based on DPPH scavenging activity assay (A) and ABTS-reducing activity assay (B).

highest $\alpha$-amylase inhibitory activity (18.18\%), compared to freeze-dried Canarium sp., freeze-dried A. bilimbi and HCA. While based on the $\mathrm{IC}_{50}$ values, HCA had the highest $\alpha$-amylase inhibitory activity $(196.16 \mu \mathrm{g} / \mathrm{mL})$, followed by freeze-dried M. domestica $(258.85 \mu \mathrm{g} / \mathrm{mL})$. While freezedried Canarium sp. had the lowest $\alpha$-amylase inhibitory activity (16496.93 $\mu \mathrm{g} / \mathrm{mL})$ (Table 3 ).

\section{Lipase Inhibitory Activity}

The lipase inhibitory activity of freeze-dried fruits and HCA were evaluated to assess the anti-obesity activity. Freeze-dried Canarium sp. had the highest lipase inhibitory activity $(77.89 \%)$ at the highest concentration tested, while $A$. bilimbi had the lowest among the three freeze-dried fruits (Figure 2B). Based on the calculated $\mathrm{IC}_{50}$ values, HCA had the best value for inhibiting the enzyme lipase $(31.22 \mu \mathrm{g} / \mathrm{mL})$, followed by freeze-dried Canarium sp. $(118.66 \mu \mathrm{g} / \mathrm{mL})$.

\section{Discussion}

Phytochemical has various biological activities underlying the utilization of plant extract as traditional medicine.(22) Some phytochemical contents, especially the phenolic and polyphenolic compound, are well known for its antioxidant capacity, since its structures are able to turn into its lessreactive form. $(23,24)$ The consumption of high phenolic content beverages, such as wine and tea, is also found to increase the serum antioxidant capacity as measured with antioxidant assay.(25,26) The phenolic and polyphenolic content in fruits are able to be metabolized and secreted by the body over a $24 \mathrm{~h}$ period after ingestion, thus further increase the safety of its consumption. $(27,28)$

Freeze-drying is one solution to keep nutritional value, antioxidant activity and phytochemical content of fruits from changing.(12,29) In present study, the phenolic and polyphenolic content of freeze-dried fruits were measured, and it was found that freeze-dried A. bilimbi had the highest phenolic content compare to the other freeze-dried fruits. However, the result of this study showed that the freeze-dried A. bilimbi and freeze-dried Canarium sp. had lower phenolic content compared to previous studies.(30,31) Meanwhile, the freeze-dried M. domestica, which contained the least phenolic content, showed similar amount of phenolic content ( $\pm 3 \mu \mathrm{g} / \mathrm{mg}$ ) compared to another study.(32)

Total flavonoid assay suggested that freeze-dried $M$. domestica had the highest flavonoid content, while freezedried Canarium sp. had the lowest. Flavonoid content of freeze-dried M. domestica found in this study was slightly

Table 2. The $\mathrm{IC}_{50}$ value of freeze-dried Canarium sp., Averrhoa bilimbi L., Malus domestica, and HCA based on DPPH scavenging activity assay and ABTS-reducing activity assay.

\begin{tabular}{lcc}
\hline \multirow{2}{*}{$\begin{array}{c}\text { Freeze-dried Fruit } \\
\text { Sample }\end{array}$} & \multicolumn{2}{c}{ IC $_{\mathbf{5 0}}(\boldsymbol{\mu g} / \mathbf{m L})$} \\
\cline { 2 - 3 } & DPPH & ABTS \\
\hline Canarium sp. & 370.84 & 1210.93 \\
Averrhoa bilimbi L. & 279.99 & 631.78 \\
Malus domestica & 805.11 & 3183.41 \\
Hydroxycitric acid & 349 & 166.23 \\
\hline
\end{tabular}



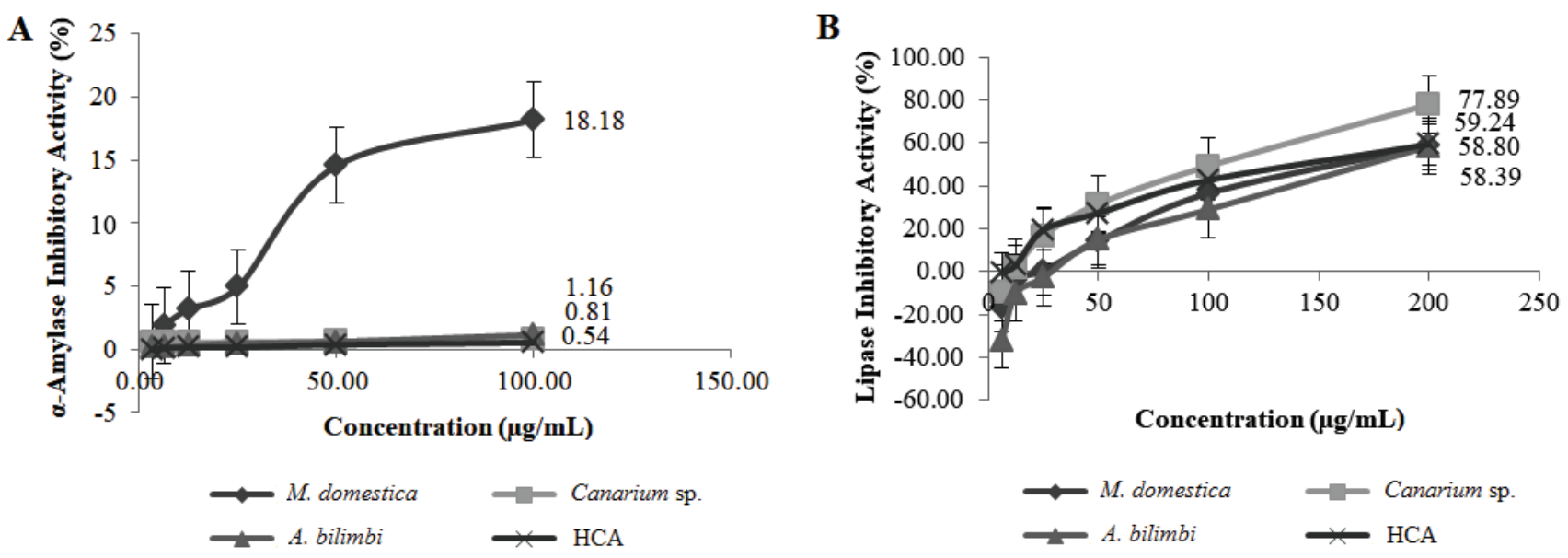

Figure 2. Concentration of freeze-dried Canarium sp., Averrhoa bilimbi L., Malus domestica, and HCA based on $\alpha$-amylase inhibitory activity assay (A) and lipase inhibitory activity assay (B).

lower compare to previous research.(33) The difference on both phenolic and flavonoid content exhibited in present study may be caused by numerous factors, including different cultivars, solvents polarity, and the extraction method used. (31) In addition, the fruit phytochemical content is also affected by different environmental conditions, ranging from the nutritional intake to the climate changes.(34)

Obesity pathogenesis was a complex process triggered by excessive fat consumption and hypoxic condition of the adipose tissue. When combined, both conditions trigger the adipocyte to produce ROS and further cause a condition known as oxidative stress. Oxidative stress stimulates the fat accumulation in adipose tissue and the differentiation of the adipocyte. $(35,36)$ Antioxidant attenuated obesity-related health effect on mice.(37) Based on both DPPH and ABTS assay, the results of this study showed that freeze-dried $A$. bilimbi had the highest antioxidant activity, which is likely due to the high phenolic content found in freeze-dried $A$. bilimbi. Thus, freeze-dried A. bilimbi has a good potential

Table 3. The $\mathrm{IC}_{50}$ value of freeze-dried Canarium sp., Averrhoa bilimbi L., Malus domestica, and HCA based on $\alpha$-amylase inhibitory activity assay and lipase inhibitory activity assay.

\begin{tabular}{lcc}
\hline \multirow{2}{*}{$\begin{array}{c}\text { Freeze-dried Fruit } \\
\text { Sample }\end{array}$} & \multicolumn{2}{c}{ IC $_{\mathbf{5 0}}(\boldsymbol{\mu g} / \mathbf{m L})$} \\
\cline { 2 - 3 } & a-Amylase & Lipase \\
\hline Canarium sp. & 16496.93 & 118.66 \\
Averrhoa bilimbi L. & 4984.57 & 165.33 \\
Malus domestica & 258.85 & 161.01 \\
Hydroxycitric acid & 196.16 & 31.22 \\
\hline
\end{tabular}

to counteract the free radicals. Antioxidant plant extract was also able to protect obese animal model from obesity related adverse health effect.(38) As evidence suggest, A. bilimbi may either prevent obesity and/or its adverse health effects through antioxidant activity by relieving the oxidative stress.

In addition to oxidative stress, inhibition of carbohydrate absorption and dietary lipid are also known to be beneficial in treating obesity. After consumption of food rich in carbohydrate, glucose concentration in plasma increased rapidly. The increased blood-sugar induces the body to store monosaccharide either as glycogen in the liver or fat in adipose tissue. Recent clinical trials conclude that the inhibition of $\alpha$-amylase promoted weight loss.(39) Previous research reported that food rich in polyphenol had potential inhibitory properties against $\alpha$-amylase and $\alpha$-glucosidase.(40) As carbohydrate digestion and obesity were linked, inhibition of enzyme may provide benefits for treating this condition. The present study found that freezedried $M$. domestica has potential $\alpha$-amylase inhibition. This activity may be related to the high polyphenolic content found in freeze-dried $M$. domestica, in this study showed by the high flavonoid content in freeze-dried $M$. domestica. This result also supported by previous research stating that $M$. domestica consumption may also limit the absorption of carbohydrate, preventing obesity.

Up until now, the inhibition of pancreatic lipase is the most widely studied mechanism for the evaluation of anti-obesity agents since inhibition of this enzyme hampers the absorption of fatty acid by the gut. $(41,42)$ Polyphenols extracted from black tea were able to inhibit the fat absorption in the gut, which occurs due to the inhibition 
of lipase enzyme.(43) The result of present study showed that the freeze-dried Canarium sp. was able to inhibit lipase activity, as having the highest lipase inhibitory activity. Freeze-dried Canarium sp. may help to prevent obesity by reducing gut fat absorption.

This study showed that freeze-dried fruit demonstrates in vitro benefit toward obesity while extending its quality and storage capability. However, further in vivo study is required to conclude the amount of freeze-dried fruit required, since the sole purpose of this study is to investigate the possible antioxidant and anti-obesity potential of freeze-dried fruit, not to determine the dosage.

\section{Conclusion}

In summary, freeze-dried fruits demonstrate in vitro benefits toward obesity. Freeze-dried A. bilimbi has potent antioxidant activity and may be beneficial against obesity-related adverse health effect by relieving oxidative stress. While freeze-dried $M$. domestica and freeze-dried Canarium sp. hamper the fat accumulation by reducing the carbohydrate absorption and dietary lipid in the digestive tract.

\section{Acknowledgements}

We are grateful to Ministry of Research, Technology and Higher Education of the Republic of Indonesia for the Research Grant of Applied Product Research (2017) for their financial support. We also gratefully acknowledge Universitas YARSI and Aretha Medika Utama Biomolecular and Biomedical Research Center for the methodology and facilities support.

\section{References}

1. World Health Organization. Obesity: preventing and managing the global epidemic. Report of a WHO consultation. World Health Organ Tech Rep Ser. 2000; 894: 1-253.

2. World Health Organization. Global Status Report on Noncommunicable Diseases 2014. Geneva: World Health Organization; 2015.

3. World Health Organization [Internet]. Obesity and Overweight [updated 2018 Feb 16; cited 2018 Dec 10]. Available from: https://www.who.int/news-room/fact-sheets/detail/obesity-andoverweight.

4. Hruby A, Hu FB. The epidemiology of obesity: a big picture. Pharmacoeconomics. 2015; 33: 673-89.

5. Walls HL, Backholer K, Proietto J, McNeil JJ. Obesity and trends in life expectancy. J Obes. 2012; 2012: 107989.
6. Wyatt SB, Winters KP, Dubbert PM. Overweight and obesity: prevalence, consequences, and causes of a growing public health problem. Am J Med Sci. 2006; 331: 166-74.

7. Marseglia L, Manti S, D’Angelo G, Nicotera A, Parisi E, Di Rosa G, et al. Oxidative stress in obesity: a critical component in human diseases. Int J Mol Sci. 2014; 16: 378-400.

8. Savini I, Catani M, Evangelista D, Gasperi V, Avigliano L. Obesityassociated oxidative stress: strategies finalized to improve redox state. Int J Mol Sci. 2013; 14: 10497-538.

9. Slanc P, Doljak B, Kreft S, Lunder M, Janeš D, Štrukelj B. Screening of selected food and medicinal plant extracts for pancreatic lipase inhibition. Phyther Res. 2009; 23: 874-7.

10. Boqué N, Campión J, de la Iglesia R, de la Garza AL, Milagro FI, San Román B, et al. Screening of polyphenolic plant extracts for anti-obesity properties in Wistar rats. J Sci Food Agric. 2013; 93: $1226-32$

11. Sagar VR, Suresh Kumar P. Recent advances in drying and dehydration of fruits and vegetables: a review. J Food Sci Technol. 2010; 47: 15-26.

12. Sanchez V, Baeza R, Chirife J. Comparison of monomeric anthocyanins and colour stability of fresh, concentrate and freezedried encapsulated cherry juice stored at $38^{\circ} \mathrm{C}$. J Berry Res. 2015; 5: 243-51.

13. Ivanova D, Gerova D, Chervenkov T, Yankova T. Polyphenols and antioxidant capacity of Bulgarian medicinal plants. J Ethnopharmacol. 2005; 96: 145-50.

14. Widowati W, Rani AP, Hamzah RA, Arumwardana S, Afifah E, Kusuma HSW, et al. Antioxidant and antiaging assays of Hibiscus sabdariffa extract and its compounds. Nat Prod Sci. 2017; 23: 192200.

15. Sudha G, Priya MS, Shree RI, Vadivukkarasi S. In Vitro Free Radical Scavenging Activity of Raw Pepino Fruit (Solanum muricatum Aiton.). Int J Curr Pharm Res. 2011; 3: 137-40.

16. Widowati W, Wargasetia TL, Afifah E, Mozef T, Kusuma HSW, Nufus $\mathrm{H}$, et al. Antioxidant and antidiabetic potential of Curcuma longa and its compounds. Asian J Agri Biol. 2018; 6: 149-161.

17. Etoundi C, Kuaté D, Ngondi J, Oben J. Anti-amylase, anti-lipase and antioxidant effects of aqueous extracts of some Cameroonian spices. J Nat Prod. 2010; 3: 165-71.

18. Widowati W, Fauziah N, Herdiman H, Afni M, Afifah E, Kusuma HSW, et al. Antioxidant and anti aging assays of oryza sativa extracts, vanillin and coumaric acid. J Nat Remedies. 2016; 16: 88.

19. Adnyana IK, Abuzaid AS, Iskandar EY, Kurniati NF. Pancreatic lipase and $\alpha$-amylase inhibitory potential of mangosteen (Garcinia mangostana Linn.) pericarp extract. Int J Med Res Heal Sci. 2016; 5: 23 .

20. Bhutkar MA. In vitro studies on alpha amylase inhibitory activity of some indigenous plants. Mod Appl Pharm Pharmacol. 2018; 2018: $1-5$.

21. Liu S, Li D, Huang B, Chen Y, Lu X, Wang Y. Inhibition of pancreatic lipase, $\alpha$-glucosidase, $\alpha$-amylase, and hypolipidemic effects of the total flavonoids from Nelumbo nucifera leaves. J Ethnopharmacol. 2013; 149: 263-9.

22. Zheng W, Wang SY. Antioxidant activity and phenolic compounds in selected herbs. J Agric Food Chem. 2001; 49: 5165-70.

23. Sulaiman CT, Sadashiva CT, George S, Goplakrishnan VK, Balachandran I. Chromatographic studies and in vitro screening for acetyl cholinesterase inhibition and antioxidant activity of three acacia species from South India. Anal Chem Lett. 2013; 3: 111-8.

24. Panche AN, Diwan AD, Chandra SR. Flavonoids: an overview. J Nutr Sci. 2016; 5: e47.

25. Tsang C, Higgins S, Duthie GG, Duthie SJ, Howie M, Mullen W, et $a l$. The influence of moderate red wine consumption on antioxidant 
status and indices of oxidative stress associated with CHD in healthy volunteers. Br J Nutr. 2005; 93: 233-40.

26. Benzie IFF, Szeto YT, Strain JJ, Tomlinson B. Consumption of green tea causes rapid increase in plasma antioxidant power in humans. Nutr Cancer. 1999; 34: 83-7.

27. Stalmach A, Steiling H, Williamson G, Crozier A. Bioavailability of chlorogenic acids following acute ingestion of coffee by humans with an ileostomy. Arch Biochem Biophys. 2010; 501: 98-105.

28. Ottaviani JI, Borges G, Momma TY, Spencer JPE, Keen CL, Crozier $\mathrm{A}$, et al. The metabolome of [2-14C](-)-epicatechin in humans: implications for the assessment of efficacy, safety and mechanisms of action of polyphenolic bioactives. Sci Rep. 2016; 6: 29034.

29. Orak H, Aktas T, Yagar H, İsbilir SS, Ekinci N, Sahin FH. Effects of hot air and freeze drying methods on antioxidant activity, colour and some nutritional characteristics of strawberry tree (Arbutus unedo L) fruit. Food Sci Technol Int. 2012; 18: 391-402.

30. Hasanuzzaman M, Ali MR, Hossain M, Kuri S, Islam MS. Evaluation of total phenolic content, free radical scavenging activity and phytochemical screening of different extracts of Averrhoa bilimbi (fruits). Int Curr Pharm J. 2013; 2: 92-6.

31. Mannan A, Rahman MM, Habib MR, Hasan MA, Al Amin M, Saha A. Comparative assessment on in vitro antioxidant activities of ethanol extracts of Averrhoa bilimbi, Gymnema sylvestre and Capsicum frutescens. Pharmacognosy Res. 2014; 6: 36-41.

32. Navarro M, Moreira I, Arnaez E, Quesada S, Azofeifa G, Vargas F, et $a l$. Polyphenolic characterization and antioxidant activity of Malus domestica and Prunus domestica cultivars from Costa Rica. Foods. 2018; 7: 15.

33. Kschonsek J, Wolfram T, Stöckl A, Böhm V. Polyphenolic compounds analysis of old and new apple cultivars and contribution of polyphenolic profile to the in vitro antioxidant capacity. Antioxidants. 2018; 7: 20.
34. Papetti A, Daglia M, Gazzani G. Anti- and pro-oxidant water soluble activity of Cichorium genus vegetables and effect of thermal treatment. J Agric Food Chem. 2002; 50: 4696-704.

35. Higuchi M, Dusting GJ, Peshavariya H, Jiang F, Hsiao STF, Chan $\mathrm{EC}$, et al. Differentiation of human adipose-derived stem cells into fat involves reactive oxygen species and forkhead Box O1 mediated upregulation of antioxidant enzymes. Stem Cells Dev. 2013; 22: 878-88.

36. Lee H, Lee YJ, Choi H, Ko EH, Kim J. Reactive oxygen species facilitate adipocyte differentiation by accelerating mitotic clonal expansion. J Biol Chem. 2009; 284: 10601-9.

37. Furukawa S, Fujita T, Shimabukuro M, Iwaki M, Yamada Y, Nakajima $\mathrm{Y}$, et al. Increased oxidative stress in obesity and its impact on metabolic syndrome. J Clin Invest. 2004; 114: 1752-61.

38. Hogan S, Canning C, Sun S, Sun X, Zhou K. Effects of grape pomace antioxidant extract on oxidative stress and inflammation in diet induced obese mice. J Agric Food Chem. 2010; 58: 11250-6.

39. Barrett ML, Udani JK. A proprietary alpha-amylase inhibitor from white bean (Phaseolus vulgaris): A review of clinical studies on weight loss and glycemic control. Nutr J. 2011; 10: 24.

40. Kwon YI, Apostolidis E, Shetty K. Inhibitory potential of wine and tea against $\alpha$-amylase and $\alpha$-glucosidase for management of hyperglycemia linked to type 2 diabetes. J Food Biochem. 2008; 32: 15-31.

41. Foster-Schubert KE, Cummings DE. Emerging therapeutic strategies for obesity. Endocr Rev. 2006; 27: 779-93.

42. Yun JW. Possible anti-obesity therapeutics from nature - A review. Phytochemistry. 2010; 71: 1625-41.

43. Yuda N, Tanaka M, Suzuki M, Asano Y, Ochi H, Iwatsuki K. Polyphenols extracted from black tea (Camellia sinensis) residue by hot-compressed water and their inhibitory effect on pancreatic lipase in vitro. J Food Sci 2012; 77: H254-61. 